\title{
PENGEMBANGAN INSTRUMEN PENILAIAN KINERJA UNTUK MENGUKUR KEMAMPUAN KREATIVITAS SISWA PADA KOMPETENSI DASAR MEMBUAT KONSEP DESAIN DAN KEMASAN PRODUK
}

\author{
THE DEVELOPMENT OF PERFORMANCE APPRAISAL INSTRUMENT TO MEASURE THE \\ ABILITY OF STUDENTS CREATIVITY IN BASIC COMPETENCIES \\ MAKING PRODUCT DESIGN CONCEPTS AND PACKAGING
}

Rizki Yanti Rahayu, Sri Handayani, Siti Mujdalipah

Program Studi Pendidikan Teknologi Agroindustri, Universitas Pendidikan Indonesia rizkiyanti8@student.upi.edu

\begin{abstract}
ABSTRAK
Penilaian kinerja peserta didik pada pembelajaran praktikum mata pelajaran Produk Kreatif dan Kewirausahaan masih sederhana dan belum memadai dalam mengukur kompetensi siswa. Guru belum sepenuhnya memahami pengembangan instrumen dan rubrik penilaian kinerja pada ranah penilaian kreativitas siswa. Tujuan penelitian ini adalah menghasilkan dan mengembangkan instrumen penilaian kinerja untuk mengukur kemampuan kreativitas siswa dengan menggunakan model pengembangan ADDIE (Analyzing, Designing, Developing, Implementing, and Evaluating). Implementasi penggunaan instrumen penilaian kinerja dilakukan untuk mengetahui kemampuan kreativitas siswa dengan menggunakan metode pre-experiment dan desain penelitian one shoot case study. Hasil penelitian menunjukkan bahwa ahli penilaian dan pengukuran serta ahli bidang pengemasan menyatakan bahwa instrumen penilaian kinerja sangat layak digunakan sebagai alat ukur tes tindakan untuk mengukur kemampuan kreativitas siswa, sementara itu hasil uji coba kepada siswa dan penilaian guru menyatakan instrumen penilaian yang dikembangkan sangat layak untuk dijadikan instrumen penilaian kinerja yang dapat mengukur kemampuan kreativitas siswa. Implementasi penggunaan instrumen penilaian kinerja menunjukkan peserta didik yang memiliki kemampuan kreativitas dengan kategori kreatif sebesar $77,78 \%$ dan sangat kreatif sebesar $22,22 \%$. Hal ini menunjukkan bahwa instrumen yang dikembangkan dapat mengukur kreativitas siswa dengan dibantu model pembelajaran berbasis proyek dan menggunakan jobsheet praktikum.
\end{abstract}

Kata kunci: penilaian kinerja, kreativitas, pengemasan

\begin{abstract}
Student performance appraisal in practicum learning in Creative Product and Entrepreneurship subjects was simple and inadequate in measuring student competency. The teacher did not fully understand the development of instruments and performance assessment rubrics in the realm of student creativity assessment. The purpose of this study was to produce and develop performance appraisal instruments to measure students' creative abilities by using the ADDIE (Analyzing, Designing, Developing, Implementing, and Evaluating) development model. Implementation of the use of performance appraisal instruments was carried out to determine the creativity abilities of students by using the pre-experiment method and the one shoot case study research design. The results showed that the assessment and measurement experts and packaging experts stated that the performance appraisal instrument was very suitable to be used as a measure of action tests to measure students' creativity abilities, while the results of trials to students and teacher assessments stated that the assessment instruments developed were very feasible to be made performance appraisal instruments that can measure students' creativity abilities. Implementation of the use of performance appraisal instruments showed students who have the ability of creativity with a creative category of $77.78 \%$ and very creative at $22.22 \%$. This shows that the instrument developed can measure student creativity with project-based learning models and using practical worksheets.
\end{abstract}

Keywords: Performance Assessment, Creativity, Packaging 


\section{PENDAHULUAN}

Pendidikan kejuruan didesain untuk membantu peserta didik untuk mempersiapkan dirinya masuk ke dunia kerja. SMK (Sekolah Menengah Kejuruan) sebagai lembaga pendidikan kejuruan harus memastikan lulusannya telah memiliki kompetensi yang sesuai dengan kebutuhan dunia kerja. Dalam rangka memastikan bahwa siswa telah memiliki kompetensi yang diharapkan perlu dilakukan penilaian pendidikan. Hasil studi pendahuluan melalui wawancara dengan beberapa orang guru dan observasi di SMK PP Negeri Tanjungsari diketahui bahwa guru-guru produktif mengalami kesulitan mengembangkan penilaian kinerja berdasarkan kurikulum 2013 revisi 2017. Karakteristik penerapan pembelajaran dalam kurikulum tersebut menekankan pada dimensi pedagogik modern dalam pembelajaran (Kemendikbud, 2017). Pendekatan ilmiah (scientific approach) sangat cocok digunakan dalam pembelajaran yang menuntut peserta didik harus memiliki keterampilan, sikap kreatif dan inovatif dalam menciptakan serta mengembangkan suatu produk (Turkmen, 2015).

Kemampuan kreatif dalam pembelajaran menuntut adanya sesuatu yang baru diciptakan. Inovasi, penemuan, dan pemecahan masalah yang dapat memperbaiki kehidupan manusia, merupakan peran kunci dari sebuah kreativitas (Fields, 2014). Aspek yang perlu diukur dalam kreativitas yaitu kelancaran, keaslian, keluwesan dan elaborasi (Almeida, 2008). Beberapa penelitian tentang penilaian kinerja dan kemampuan kreatif menunjukkan bahwa instrumen penilaian kinerja dapat membantu dalam mengembangkan dan mengidentifikasi kemampuan kreativitas peserta didik (Wening, 2014; Marwiyah, 2015).

Pengemasan merupakan bagian yang tidak terpisahkan dalam kegiatan penanganan dan pengolahan hasil pertanian, dimulai dari bahan berada di tempat pemanenan sampai ke konsumen. Di SMK PP Negeri Tanjungsari Program Keahlian APHP (Agribisnis Pengolahan Hasil Pertanian) terdapat permasalahan dalam proses pengemasan produk diantaranya siswa masih belum memperhatikan fungsi dalam melindungi kelompok-kelompok kemasan, padahal kualitas barang sangat diperhatikan. Selain itu kemasan produk yang dihasilkan dan digunakan hanya satu jenis kemasan saja yaitu plastik yang diberi label dan nama produk saja padahal produk yang dijual bermacam-macam. Tujuan penelitian ini adalah menghasilkan Instrumen Penilaian Kinerja untuk mengukur kemampuan kreativitas siswa pada Kompetensi Dasar Membuat Konsep Desain dan Kemasan Produk serta mengetahui kemampuan kreativitas siswa dengan menggunakan Instrumen Penilaian Kinerja pada Kompetensi Dasar Membuat Konsep Desain dan Kemasan Produk.

\section{METODE PENELITIAN}

Pengembangan instrumen penilaian kinerja untuk mengukur kemampuan kreativitas siswa menggunakan model pengembangan ADDIE (Analisis, Desain, Pengembangan, Implementasi, dan Evaluasi). Sedangkan untuk penelitian pada implementasi penggunaan instrumen penilaian kinerja untuk mengukur kemampuan kreativitas siswa menggunakan metode pre-eksperimen dengan desain penelitian one shoot case study. Partisipan pada penelitian ini adalah siswa kelas $\mathrm{XI}-\mathrm{K}$ Program Keahlian APHP SMK PP Negeri Tanjungsari sebanyak 30 orang (9 orang untuk ujicoba instrumen penilian kinerja dan 21 orang untuk implementasi penggunaan instrumen penilaian kinerja). Teknik pengumpulan data yang digunakan pada penelitian ini adalah studi dokumentasi, angket, dan tes kinerja.

\section{Analisis Data}

Analisis data pada pengembangan instrument penilian kinerja menggunakan metode CVR (Content Validity Rasio) dan CVI (Content Validity Index). Validitas isi dilakukan untuk memperoleh informasi tentang kecocokan antara item tes dengan indikator yang telah dikonstruksi, validitas isi dilaksanakan oleh para pakar (Ratnasusanti, 2018). Tahapan pengolahan validasi instrumen dilakukan dengan cara pemberian kriteria tanggapan validator dan guru yaitu layak (1) dan tidak layak (0). Hasil perhitungan CVR dan CVI dinyatakan dengan persentase, $0-33 \%$ dinyatakan tidak layak, $34-67 \%$ dinyatakan layak, dan $68-100 \%$ dinyatakan sangat layak. Analisis tersebut 
digunakan untuk menentukan kualitas aspek isi, kontruk, dan bahasa pada instrumen penilaian kinerja yang dikembangkan.

Analisis data untuk penerapan penggunaan instrumen penilaian kinerja untuk mengukur kemampuan kreativitas siswa menggunakan metode statistik deskriptif kuantitatif. Rentang nilai untuk masing-masing skor indikator penilaian kinerja dengan skor rentang 0-4, rentang skor digunakan untuk seluruh elemen atau indikator penilaian kinerja yang akan dinilai. Bobot untuk masing-masing indikator ditentukan dengan persentase, sehingga jumlahnya mencapai 100 persen. Bobot pada aspek persiapan kerja $10 \%$, proses $30 \%$, hasil kerja $30 \%$, sikap kerja $20 \%$, dan waktu 10\% (BNSP, 2018). Rata-Rata Skor Tiap Kategori (RTK) tersebut dikonversikan dalam bentuk kriteria kemampuan kreativitas siswa, yang tersaji dalam Tabel 1.

Tabel. 1 Kriteria Kemampuan Kreativitas Siswa

\begin{tabular}{|l|l|}
\hline Persentase $(\%)$ & Kategori \\
\hline $0-25,0$ & Kurang Kreatif \\
\hline $26,0-50,0$ & Cukup Kreatif \\
\hline $51,0-75,0$ & Kreatif \\
\hline $76,0-100,0$ & Sangat Kreatif \\
\hline
\end{tabular}

\section{HASIL DAN PEMBAHASAN}

\section{Pengembangan Instrumen Penilaian Kinerja}

Analisis (Analysis)

Tahapan analisis dilakukan dengan observasi dan wawancara, hasil yang diperoleh berupa masalah yang memerlukan perhatian yaitu guru-guru belum sepenuhnya memahami bagaimana mengembangkan instrumen dan rubrik penilaian kinerja pada ranah penilaian kreativitas siswa sehingga kompetensi siswa tidak terukur dengan baik. Selain itu Kemasan produk yang dihasilkan dan digunakan hanya satu jenis kemasan saja yaitu plastik yang diberi label dan nama produk saja padahal produk yang dijual bermacam-macam.

Temuan dari analisis peserta didik pada Program Keahlian APHP SMK PP Negeri Tanjungsari adalah peserta didik berusia diantara 16-18 tahun. Menurut Santrock (2011), pada rentang usia tersebut perkembangan kognitif individu berada pada daerah tugas-tugas yang sangat sulit untuk diatasi oleh individu secara sendirian, tetapi baru dapat dicapai apabila mendapat bimbingan atau bantuan dari orang dewasa atau teman sebaya yang lebih terampil. Peneliti mengembangkan penilaian kinerja agar peserta didik tidak lagi merasa abstrak terhadap materi yang diperolehnya karena terdapat tugas kinerja yang dapat dilakukan sehingga bisa membuat peserta didik terlatih dalam mengkonstruk pengetahuannya dalam kehidupan nyata. Temuan di lapangan pun siswa lebih menyukai cara belajar secara praktek dibandingkan dengan belajar teori di kelas. Hampir seluruh siswa menyukai cara belajar visual dan kinestetik, karena mereka mudah menangkap materi dengan cara belajar tersebut.

Kompetensi dasar yang dipilih peneliti adalah materi membuat desain dan kemasan produk. Kompetensi dasar ini dipilih karena dianggap sebagai salah satu kompetensi yang memuat dimensi pengetahuan yang sifatnya prosedural dan menguatkan keterampilan dan sikap kerja, sehingga kompetensi dasar ini memungkinkan untuk dilakukannya kegiatan praktikum. Kegiatan praktikum yang dilakukan terkait beberapa aktivitas yang dapat diamati seperti persiapan kerja, proses kerja, hasil kerja, sikap kerja, dan waktu penyelesaian praktek. Berdasarkan pada analisis peserta didik dan analisis materi, maka tugas yang diberikan yakni berupa tugas kinerja melalui pembelajaran model pembelajaran Project Based Learning (PjBL) dengan dibantu jobsheet sebagai pedoman praktikum. Kegiatan praktikum ini merupakan tugas yang tidak sulit untuk dilakukan, alat/bahan yang digunakan juga mudah untuk dijangkau serta mampu menumbuhkan kreativitas peserta didik dengan terlibat secara langsung dalam proses pembelajaran. 


\section{Desain}

Perancangan instrumen Penilaian kinerja terdiri dari pemilihan format dan perancangan prototype awal.

1. Pemilihan Format

Pemilihan format dilakukan agar tidak menyerupai format penilaian yang telah ada sebelumnya melalui penentuan kriteria yang akan dinilai dalam kinerja peserta didik. Kriteria yang dipilih peneliti adalah kemampuan kreativitas siswa ketika persiapan kerja, proses kerja, hasil kerja, sikap kerja, dan waktu penyeleaian dalam mengerjakan tugas kegiatan praktikum. Kriteria yang ditentukan membantu dalam penyusunan petunjuk penggunaan, tugas kinerja, dan rubrik penilaian kinerja.

2. Rancangan Awal Instrument Penilaian Kinerja

Rancangan awal produk memuat sampul penilaian kinerja, petunjuk penggunaan instrumen yang terdiri atas petunjuk umum dan petunjuk khusus, kisi-kisi sebagai patokan dalam membuat aspek/kinerja yang akan dinilai, rubrik serta penskoran. Aspek/kinerja yang akan dinilai dibuat berdasarkan kisi-kisi yang bersumber dari BNSP (2018) yang menjadi pedoman penskoran dalam menilai kinerja peserta didik. Aspek/kinerja yang dinilai yaitu persiapan kerja, proses kerja, hasil kerja, sikap kerja, dan waktu penyelesaian yang dipadukan dengan aspek-aspek yang ada di creativity skills (fluency, flexibility, elaboration, dan originality). Penyusunan dilakukan dengan menentukan terlebih dahulu apakah cara yang digunakan berupa daftar cek (Check-list) atau skala penilaian (Rating scale). Setelah diperoleh aspek/ kinerja yang akan dinilai, barulah rubrik penilaian dibuat dengan menggunakan skala penilaian (Rating scale) secara analitik. Rubrik penilaian skala analitik ini terdiri atas 5 kriteria, yakni sangat kreatif dengan nilai 4, kreatif dengan nilai 3, cukup kreatif dengan nilai 2, kurang kreatif dengan nilai 1, dan tidak kreatif dengan nilai 0 . Kelima kriteria ini masing-masing terdapat keterangan terhadap aspek yang akan dinilai. Selain itu, dibuat pula lembar penskoran sekaligus sebagai rekapitulasi hasil penilaian kinerja kemampuan kreativitas yang akan diisi oleh guru.

\section{Pengembangan (Development)}

Pada tahap ini, Instrument Penilaian Kinerja untuk mengukur kemampuan kreativitas siswa yang dirancang akan direvisi berdasarkan masukan dari judgment expert yang selanjutnya digunakan dalam tahap uji coba.

1. Validasi Instrumen Penilaian Kinerja Kemampuan Kreativitas

Validasi pada pengembangan instumen Penilaian Kinerja untuk mengukur kemampuan kreativitas siswa dilakukan untuk mengetahui pendapat ahli dan mengukur kelayakan instrumen yang dikembangkan sebelum ke tahapan implementasi. Penilaian ahli terhadap pengembangan instrument Penilaian Kinerja menggunakan pedoman penilaian kelayakan instrumen PA dari Basri (2017) meliputi aspek isi, konstruksi, dan bahasa. Data hasil validasi instrumen penilaian kinerja untuk mengukur kemampuan kreativitas terdapat pada gambar 1.

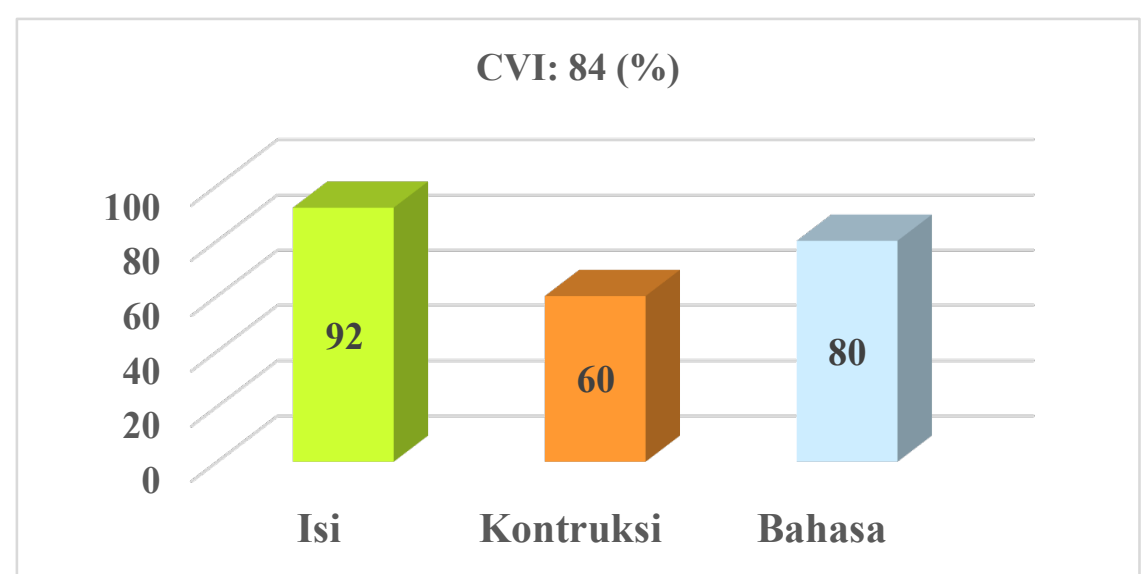

Gambar 1. Hasil Validasi Judgment Expert Bidang Ahli Evaluasi Pembelajaran dan Pengemasan 
Hasil penilaian ahli terhadap aspek isi, kontruksi, dan bahasa mempunyai nilai CVI 0,84 atau dikonversi ke persentase menjadi $84 \%$ termasuk kedalam kategori "sangat layak" untuk digunakan walaupun ada beberapa perbaikan berdasarkan saran yang diberikan oleh validator, maka dari itu peneliti harus melakukan perbaikan sebelum ke tahapan ujicoba (Implementasi). Miranti (2013) menyatakan salah satu prinsip utama dalam penentuan tugas dan kriteria kinerja dalam instrumen Penilaian Kinerja adalah harus sesuai dengan kurikulum, silabus, indikator, dan tujuan pembelajarannya. Instrumen Penilaian Kinerja harus menjabarkan secara jelas dan sistematis task beserta rubrik yang nantinya akan memberikan pengalaman belajar yang berhargaserta menuntut siswa mengeluarkan potensi dan kemampuan yang dimilikinya (Moskal, 2003). Intrumen Penilaian Kinerja memiliki rubrik dalam bentuk instrumen penilaian khusus untuk menilai dan mengevaluasi penampilan siswa atau menilai produk yang dihasilkan sebagai penyelesaian tugas kinerja (Maertler, 2001). Rubrik merupakan panduan penilaian berbasis kriteria yang terdiri dari pengukuran tetap dan deskripsi karakteristik untuk setiap nilai skor. Rubrik harus dapat menggambarkan derajat kualitas, kemampuan peserta didik ketika untuk kerja (Wiggins, 2005). Kontruksi kalimat pada kriteria penilaian harus detail/rinci dan bisa mengukur secara akurat kemampuan peserta didik ketika unjuk kerja ketika praktek (Reynolds, 2010). Yuniarti (2012), menjelaskan kualitas bahasa seperti penggunaan kata yang tepat dapat mengurangi terjadinya miskonsepsi dan kesenjangan informasi.Bahasa yang digunakan pada instrumen penilaian kinerja komunikatif, sederhana, terstuktur dengan baik dan benar agar memudahkan penilai ketika menggunakan intrumen tersebut (Ratnasusanti, 2018).

\section{Implementasi}

Tahap implementasi pada model pengembangan ADDIE dilakukan untuk mendapatkan informasi mengenai kelayakan instrumen penilaian kinerja untuk mengukur kemampuan kreativitas siswa dari hasil uji coba instrumen kepada peserta didik dan penilaian guru terhadap instrumen penilaian kinerja yang sedang dikembangkan. Peserta didik yang dijadikan untuk ujicoba instrumen sebanyak 9 orang dan 3 orang guru APHP SMK Negeri Tanjungsari yang mengobservasi tes kinerja peserta didik ketika praktek membuat desain dan kemasan produk. Setelah mengobservasi peserta didik, guru pun memberikan penilaian kelayakan instrumen penilaian kineja untuk mengukur kemampuan kreativitas siswa. Data hasil yang diperoleh dari uji coba pada tahapan implementasi dapat dilihat pada Tabel 2 dan data hasil penilaian guru terhadap kelayakan instrumen penilian kinerja tersaji pada gambar 2 .

Tabel 2. Hasil Uji Coba Instrumen Penilaian Kinerja untuk Mengukur Kemampuan Kreativitas Siswa

\begin{tabular}{|c|c|c|c|c|c|}
\hline \multirow{2}{*}{$\frac{y}{\frac{0}{d}}$} & \multirow{2}{*}{$\begin{array}{l}\text { Komponen/Sub } \\
\text { Penilaian }\end{array}$} & \multicolumn{4}{|c|}{ Hasil Penilaian Kinerja (\%) } \\
\hline & & $\begin{array}{l}\text { Kurang } \\
\text { Kreatif }\end{array}$ & $\begin{array}{l}\text { Cukup } \\
\text { Kreatif }\end{array}$ & $\overline{\text { Kreatif }}$ & $\begin{array}{l}\text { Sangat } \\
\text { Kreatif }\end{array}$ \\
\hline \multirow{3}{*}{ 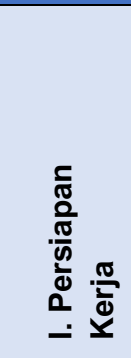 } & $\begin{array}{l}\text { 1.1.Mengajukan/mencetuskan } \\
\text { ide/gagasan membuat kemasan } \\
\text { (Fluency) }\end{array}$ & $11,11 \%$ & $22,22 \%$ & $55,56 \%$ & $11,11 \%$ \\
\hline & $\begin{array}{l}\text { 1.2. Menyusun rencana } \\
\text { pembuatan produk kemasan } \\
\text { (Fluency). }\end{array}$ & $0 \%$ & $44,44 \%$ & $33,33 \%$ & $22,22 \%$ \\
\hline & $\begin{array}{l}\text { 1.3. Menuliskan cara kerja dan } \\
\text { diagram alir (Elaboration). }\end{array}$ & $22,22 \%$ & $11,11 \%$ & $33,33 \%$ & $33,33 \%$ \\
\hline \multirow{3}{*}{ 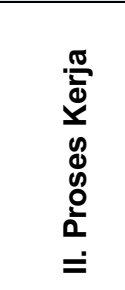 } & $\begin{array}{l}\text { 2.1. Memilih dan menangani } \\
\text { jenis bahan kemasan (Flexibility) }\end{array}$ & $0 \%$ & $11,11 \%$ & $55,56 \%$ & $33,33 \%$ \\
\hline & $\begin{array}{l}2.2 . \quad \text { Membuat } \quad \text { kemasan } \\
\text { berdasarkan klasifikasinya } \\
\text { (Flexibility) }\end{array}$ & $0 \%$ & $0 \%$ & $66,67 \%$ & $33,33 \%$ \\
\hline & $\begin{array}{l}\text { 2.3. Membuat kemasan berdasar } \\
\text { kansyarat memilih kemasan }\end{array}$ & $0 \%$ & $0 \%$ & $66,67 \%$ & $33,33 \%$ \\
\hline
\end{tabular}




\begin{tabular}{|c|c|c|c|c|c|}
\hline \multirow{2}{*}{$\frac{\frac{1}{6}}{\frac{0}{4}}$} & \multirow{2}{*}{$\begin{array}{l}\text { Komponen/Sub Komponen } \\
\text { Penilaian }\end{array}$} & \multicolumn{4}{|c|}{ Hasil Penilaian Kinerja (\%) } \\
\hline & & $\begin{array}{l}\text { Kurang } \\
\text { Kreatif }\end{array}$ & $\begin{array}{l}\text { Cukup } \\
\text { Kreatif }\end{array}$ & Kreatif & $\begin{array}{l}\text { Sangat } \\
\text { Kreatif }\end{array}$ \\
\hline & (Flexibility) & & & & \\
\hline & $\begin{array}{l}\text { 2.4. Membuat label kemasan } \\
\text { (Flexibility) }\end{array}$ & $0 \%$ & $11,11 \%$ & $77,78 \%$ & $11,11 \%$ \\
\hline & $\begin{array}{l}\text { 2.5.Membuat analisis biaya } \\
\text { produk kemasan (Elaboration) }\end{array}$ & $0 \%$ & $0 \%$ & $77,78 \%$ & $22,22 \%$ \\
\hline \multirow{3}{*}{ 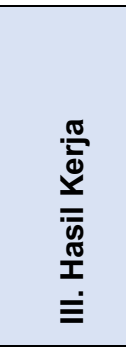 } & $\begin{array}{lcl}\text { 3.1. } & \text { Menghasilkan } & \text { label } \\
\text { kemasan (orisinalitas) } & \end{array}$ & $0 \%$ & $0 \%$ & $77,78 \%$ & $22,22 \%$ \\
\hline & $\begin{array}{lrl}\text { 3.2. } & \text { Menghasilkan } & \text { label } \\
\text { kemasan (orisinalitas) } & \\
\end{array}$ & $0 \%$ & $0 \%$ & $88,89 \%$ & $11,11 \%$ \\
\hline & $\begin{array}{l}\text { 3.3 Mampu membuat kombinasi- } \\
\text { kombinasi yang baru dan unik } \\
\text { dari bagian-bagian kemasan } \\
\text { (orisinalitas) }\end{array}$ & $0 \%$ & $33,33 \%$ & $55,56 \%$ & $11,11 \%$ \\
\hline \multirow{2}{*}{ 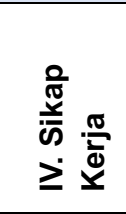 } & $\begin{array}{l}\text { 4.1. Mampu bersikap kreatif, } \\
\text { inovatif, disiplin, dan tanggung } \\
\text { jawab. }\end{array}$ & $0 \%$ & $0 \%$ & $66,67 \%$ & $33,33 \%$ \\
\hline & $\begin{array}{lcc}4.2 & \text { Mampu } & \text { melakukan } \\
\text { keselamatan kerja } & \end{array}$ & $0 \%$ & $0 \%$ & $66,67 \%$ & $33,33 \%$ \\
\hline 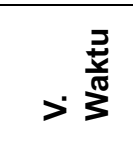 & $\begin{array}{l}\text { 5.1. Tugas-tugas penyelesaian } \\
\text { produk }\end{array}$ & $0 \%$ & $33,33 \%$ & $44,44 \%$ & $22,22 \%$ \\
\hline
\end{tabular}

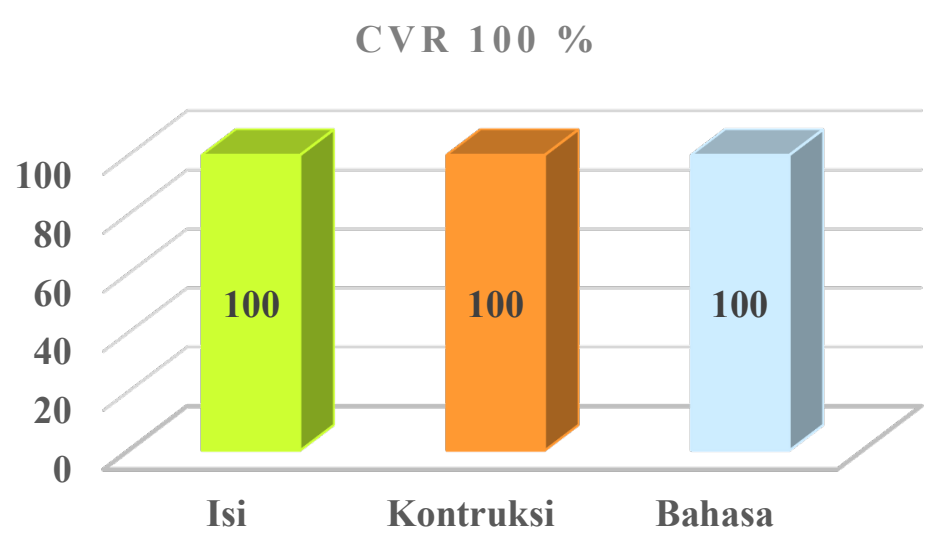

Gambar. 2 Data Angket Penilaian Guru Terhadap Kelayakan Instrumen Penilaian Kinerja

Hasil uji coba pada tahap implementasi instrumen penilaian kinerja menyatakan rata-rata siswa memiliki nilai 70,7 dengan kategori kreatif, sementara itu hasil penilaian guru terhadap aspek isi, kontruksi, dan bahasa mempunyai nilai CVI 1 atau dikonversi ke persentase menjadi 100\% termasuk ke dalam kategori "sangat layak". Sesuai hasil uji coba instrumen penilaian kinerja dan angket penilaian guru menunjukkan bahwa instrumen yang dikembangkan sangat layak untuk dijadikkan alat evaluasi tes kinerja terutama untuk mengukur kemampuan kreativitas siswa. Instrumen penilaian yang baik memiliki petunjuk penggunaan dan pengisiian agar pengguna dapat mengisi dan mengolah hasil data dengan baik dan terhindar dari kesalahan (Ramdani, 2019). Penentuan tugas dan kriteria penilaian dalam instrumen penilaian kinerja ditentukan dari hasil analisis materi dan analisis tugas yang sebelumnya mengkaji dokumen seperti kurikulum, silabus, indikator pembelajaran pada kompetensi tertentu (Basri, 2017). Kriteria penilaian dapat menjadi pedoman penilaian yang objektif dan konsisten dengan kriteria yang jelas. Rubrik dapat memberikan informasi bobot penilaian dan dapat memotivasi peserta didik untuk belajar lebih aktif. Peserta didik dapat 
menggunakan rubrik untuk mengukur capaian kemampuannya sendiri serta akan mendapatkan umpan balik yang cepat dan akurat. Rubrik dapat digunakan sebagai intrumen untuk refleksi yang efektif tentang proses pembelajaran yang telah berlangsung dan pedoman dalam proses belajar maupun penilaian hasil belajar penilaian (Magdalena, 2016).

\section{Evaluasi}

Produk akhir penelitian pengembangan ini adalah produk hasil evaluasi dan perbaikan dari semua tahapan ADDIE berupa instrumen penilian kinerja yang dapat mengukur kemampuan kreativitas siswa. Hasil validasi dari ahli penilaian dan pengukuran serta ahli bidang pengemasan menyatakan bahwa instrumen penilaian kinerja sangat layak serta dapat dilanjutkan ke tahapan implementasi. Sementara itu hasil ujicoba instrumen kepada siswa dan penilaian guru terhadap instrumen yang dikembangkan menyatakan sangat layak untuk dijadikan instrumen penilaian kinerja yang mengukur kreativitas siswa.

\section{Penggunaan Instrumen Penilaian Kinerja Untuk Mengukur Kreativitas Siswa pada Kompetensi Dasar Membuat Konsep Desain dan Kemasan Produk}

Implementasi penggunaan instrumen penilaian kinerja dilakukan setelah Model Pengembangan ADDIE selesai yang menyatakan Instrumen penilaian kinerja dinyatakan layak untuk digunakan dalam proses pembelajaran dan dapat mengukur kemampuan kreativitas siswa. Adanya studi kasus menuntut peserta didik untuk mengeluarkan kemampuan kreativitas yang ada didalam dirinya seperti fluency (kelancaran respon), flexibility (fleksibelitas respon), originality (keaslian respon), dan elaboration (perluasan respon). Kemampuan kreativitas ini diuji dan disesuaikan dengan aspek penilaian kinerja yang mencakup (1) persiapan kerja, (2) proses kerja, (3) hasil kerja, (4) sikap kerja dan (5) waktu penyelesaian.

Data hasil penilaian kinerja untuk mengukur kreativitas siswa dalam membuat kemasan pasa aspek persiapan kerja sampai aspek waktu penyelesaian dapat dilihat pada pada Tabel 3.

Tabel 3. Hasil Penilaian Kinerja Kreativitas Siswa

\begin{tabular}{|c|c|c|c|c|c|}
\hline \multirow{2}{*}{ Aspek } & \multirow{2}{*}{$\begin{array}{l}\text { Komponen/SubkomponenPenila } \\
\text { ian }\end{array}$} & \multicolumn{4}{|c|}{ Hasil Penilaian Kinerja ( $\%)$} \\
\hline & & Kurang Kreatif & Cukup Kreatif & Kreatif & Sangat Kreatif \\
\hline \multirow{3}{*}{ 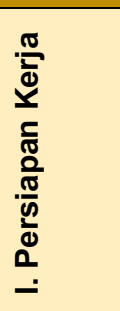 } & $\begin{array}{l}\text { 1.1.Mengajukan/mencetuskan } \\
\text { ide/gagasan membuat kemasan } \\
\text { (Fluency) }\end{array}$ & $0 \%$ & $5,55 \%$ & $77,78 \%$ & $16,67 \%$ \\
\hline & $\begin{array}{l}\text { 1.2. Menyusun rencana pembuatan } \\
\text { produk kemasan (Fluency). }\end{array}$ & $0 \%$ & $5,55 \%$ & $77,78 \%$ & $16,67 \%$ \\
\hline & $\begin{array}{l}\text { 1.3. Menuliskan cara kerja dan } \\
\text { diagram alir (Elaboration). }\end{array}$ & $0 \%$ & $16,67 \%$ & $66,67 \%$ & $16,67 \%$ \\
\hline \multirow{5}{*}{ 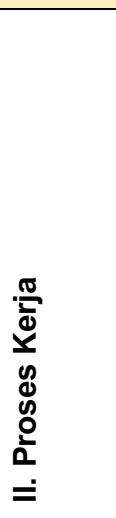 } & $\begin{array}{l}\text { 2.1. Memilih dan menangani jenis } \\
\text { bahan kemasan (Flexibility) }\end{array}$ & $0 \%$ & $16,67 \%$ & $66,67 \%$ & $16,67 \%$ \\
\hline & $\begin{array}{lr}2.2 . \quad \text { Membuat } & \text { kemasan } \\
\text { berdasarkan } & \text { klasifikasinya } \\
\text { (Flexibility) } & \\
\end{array}$ & $0 \%$ & $5,55 \%$ & $77,78 \%$ & $16,67 \%$ \\
\hline & $\begin{array}{lr}2.3 . \quad \text { Membuat } & \text { kemasan } \\
\text { berdasarkansyarat } & \text { memilih } \\
\text { kemasan (Flexibility) } & \\
\end{array}$ & $0 \%$ & $11,11 \%$ & $72,22 \%$ & $16,67 \%$ \\
\hline & $\begin{array}{l}\text { 2.4. Membuat label kemasan } \\
\text { (Flexibility) }\end{array}$ & $0 \%$ & $11,11 \%$ & $72,22 \%$ & $16,67 \%$ \\
\hline & $\begin{array}{l}\text { 2.5.Membuat analisis biaya produk } \\
\text { kemasan (Elaboration) }\end{array}$ & $0 \%$ & $16,67 \%$ & $61,11 \%$ & $22,22 \%$ \\
\hline \multicolumn{2}{|c|}{ 交 $\bar{n} !^{3.1 .}$} & $0 \%$ & $16,67 \%$ & $77,78 \%$ & $5,55 \%$ \\
\hline
\end{tabular}




\begin{tabular}{|c|c|c|c|c|c|}
\hline \multirow{2}{*}{ Aspek } & \multirow{2}{*}{$\begin{array}{l}\text { Komponen/SubkomponenPenila } \\
\text { ian }\end{array}$} & \multicolumn{4}{|c|}{ Hasil Penilaian Kinerja (\%) } \\
\hline & & Kurang Kreatif & Cukup Kreatif & Kreatif & Sangat Kreatif \\
\hline & 3.2. Menghasilkan label kemasan & $0 \%$ & $38,89 \%$ & $50 \%$ & $11,11 \%$ \\
\hline & $\begin{array}{l}\text { 3.3 Mampu membuat kombinasi- } \\
\text { kombinasi yang baru dan unik dari } \\
\text { bagian-bagian }\end{array}$ & $0 \%$ & $27,78 \%$ & $61,11 \%$ & $11,11 \%$ \\
\hline$\frac{\frac{2}{\pi}}{\bar{\pi}}$ & $\begin{array}{l}\text { 4.1. Mampu bersikap kreatif, } \\
\text { inovatif, disiplin, dan tanggung } \\
\text { jawab. }\end{array}$ & $0 \%$ & $11,11 \%$ & $77,78 \%$ & $11,11 \%$ \\
\hline 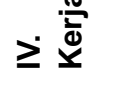 & $\begin{array}{l}4.2 \quad \text { Mampu } \quad \text { melakukan } \\
\text { keselamatan kerja }\end{array}$ & $0 \%$ & $11,11 \%$ & $66,67 \%$ & $16,67 \%$ \\
\hline$>\frac{\frac{7}{\sqrt{1}}}{3}$ & $\begin{array}{l}\text { 5.1. Tugas-tugas penyelesaian } \\
\text { produk }\end{array}$ & $0 \%$ & $5,55 \%$ & $83,33 \%$ & $11,11 \%$ \\
\hline
\end{tabular}

Hasil implementasi penggunaan instrumen penilaian kinerja pada praktikum membuat konsep desain dan kemasan produk menunjukkan bahwa peserta didik yang memiliki kemampuan kreativitas dengan kategori kreatif sebesar $77,78 \%$ dan sangat kreatif sebesar $22,22 \%$. Menurut Sandrayani (2011) dan Munandar (1987), kreativitas secara umum sebagai proses memahami suatu masalah, mencari solusi-solusi yang mungkin dilakukan, membuat hipotesis, menguji dan mengevaluasi, dan mengkomunikasikan hasilnya. Secara operasional, kreativitas dapat dirumuskan sebagai kemampuan memberi gagasan secara lancar, lentur, dan orisinil, serta mampu mengelaborasi suatu gagasan. Hal ini menunjukkan pula bahwa instrumen yang dikembangkan dapat mengukur kemampuan kreativitas siswa dengan dibantu pendekatan berbasis proyek dan menggunakan jobsheet sebagai panduan pembelajarannya. Model Pembelajaran PJBL dengan dibantu jobsheet dan diukur dengan instrument penilaian kinerja dapat meningkatkan kreativitas siswa karena mendorong siswa untuk menghasilkan suatu cara atau suatu yang baru dalam menghadapi masalah atau situasi. Selain itu siswa akan terdorong untuk meneliti, merencanakan, mendesain, dan merefleksikan terhadap pembuatan projek. Instrumen penilian kinerja akan merefleksikan apa yang dilakukan oleh siswa ketika mengerjakan sebuah proyek kreatif yang dibuat (Sari, 2018).

\section{KESIMPULAN}

Tahapan pengembangan instrumen penilaian kinerja untuk mengukur kemampuan kreativitas siswa meliputi analisis, desain, pengembangan, implementasi, dan evaluasi. Tahap analisis terdiri dari analisi, analisis peserta didik, analisis materi, analisis tugas, dan perumusan tujuan pembelajaran. Tahap perancangan dalam pembuatan produk dimulai dari pembuatan pemilihan format dan perancangan awal produk. Secara keseluruhan dari hasil tahapan development, Ahli penilaian dan pengukuran serta ahli bidang pengemasan menyatakan bahwa instrumen penilaian kinerja sangat layak digunakan sebagai alat ukur tes tindakan untuk mengukur kemampuan kreativitas siswa dengan nilai CVI 84\%, sementara itu hasil uji coba kepada siswa dan penilaian guru menyatakan instrumen penilaian yang dikembangkan sangat layak untuk dijadikan instrumen penilaian kinerja dengan nilai CVI 100\% serta hasil kreativitas siswa pada saat ujicoba instrument rata-rata nilai sebesar 70,7 dengan kategori kreatif.

Hasil implementasi penggunaan instrumen penilaian kinerja di kelas XI-K APHP SMK PP Negeri Tanjungsari pada praktikum membuat konsep desain dan kemasan produk menunjukkan bahwa peserta didik yang memiliki kemampuan kreativitas dengan kategori kreatif sebesar $77,78 \%$ 
dan sangat kreatif sebesar $22,22 \%$. Hal ini menunjukkan pula bahwa instrumen yang dikembangkan dapat mengukur kemampuan kreativitas siswa dengan dibantu pendekatan berbasis proyek dan menggunakan jobsheet sebagai panduan pembelajarannya.

\section{DAFTAR PUSTAKA}

Almeida, L.S. (2008). Torrance Test of Creative Thinking: The Question of Its Construct Validity. Jurnal Thinking Skill and Creativity 3: 53-58. doi:10.1016/j.tsc.2008.03.003.

Basri, Q. (2017). Pengembangan Penilaian Kinerja Teknik Peer Assessment paa Pembelajaran Biologi Kelas XI di MA Alauddin.

BNSP. 2018. Instrumen Penilaian Buku Teks Pelajaran Pendidikan Dasar dan Menengah. Jakarta: BSNP.

Direktorat Pembinaan Sekolah Menengah Kejuruan Kementerian Pendidikan dan Kebudayaan Republik Indonesia. (2013). Penanganan Bahan Hasil Pertanian dan Perikanan.

Fields, Z., dan Christo, A.B. ( 2014). Developing and Assessing a Tool to Measure the Creativity of University Students." J Soc Sci 38: 23-31.

Maertler, C.A. (2001). "Designing Scoring Rubrics for Your Classroom." A Peer-Reviewed Electronic Journal 7: 1-8.

Magdalena S. H. (2016). Penilaian Pembelajaran Melalui Rubrik. Universitas Katolik Atma Jaya.

Marwiyah, S. (2015). "Development of Instrument Assessment of Creative Thinking Integrated Science in Studying Atom, Ion, and Molecule Material on AI Falah Islamic Junior High School." Jurnal Edu-Sains 4: 26-31.

Munandar , S.C. Utami. (1987). Kreativitas Sepanjang Masa. Jakarta: Muliasari.

Wening, S. (2014). "The Effectiveness Of Using Instrumen and Rubric Of Creative Thingking SkillBased Asessment Project In The Leraning Of Consumer Eduation." Yogjakarta.

Miranti, M. G. (2013). Pengembangan Instrumen Penilaian kinerja untuk Menilai Ketercapaian Kompetensi dalam Pembelajaran Patiseri. [Tesis]. Universitas Pendidikan Indonesia.

Moskal. (2003). Recommendations for developing classroom performance assessments and scoring rubrics. A peer-reviewed electronic journal. Vol. 8: 1-9.Doi. ISSN 1531-7714.

Padmanatali, Omega. (2012). Peningkatan Kreativitas Membuat Produk Pengawetan Melalui Model Pembelajran STAD Pada Siswa SMO Kristen Bentara Wacana Muntilan. S1 Thesis, UNY.

Ramdani, F. (2019). Development of Virtual Laboratory of Food Microbiology Based Websites. Universitas Pendidikan Indonesia.

Ratnasusanti, H. (2018). Penilaian kinerja untuk Mengukur Creative Thinking Skill Siswa pada Pembelajaran Prakarya SMP. [Tesis] Universitas Pendidikan Indonesia.

Reynolds, C.R. Livingstone, R.B. \& Wilson, V. (2010). Measurement and Assessment in Education. Second Edition. Pearson, New Jersey.

Santrock, J. (2011). Masa Perkembangan Anak. Jakarta Salemba Humanika.

Sandrayani, D. (2011). Meningkatkan Kreativitas pada Mahasiswa Desain Komunikasi Visual. [Tesis] Universitas Pelita Harapan.

Sari, Rona Tula. (2018). Penerapan Model Pembelajran PJBL Upaya Peningkatan Kreativitas Mahasiswa. FKIP. UBH.

Turkmen, H. (2015). "Creative Thingking Skill Analiyzes of Vocational High School Student." Journal Of Education and Intructional Studies V: 74-84.

Wiggins, G., \& McTighe, J. (2005). Understanding by Design (2nd ed.). Alexandria, VA: Association for Supervision and Curriculum Development.

Yuniarti,. (2012). The Content of Indonesian Child-Parent Attachment. International Society for The Study of Behavioral Development (2): 11-15. 